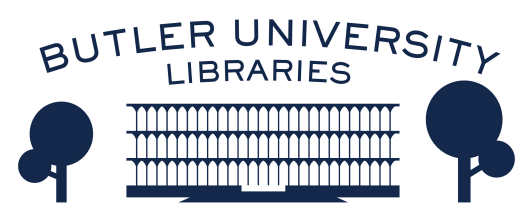

Journal of Hindu-Christian Studies

Volume 24

Article 19

November 2011

\title{
Book Review: "The New Comparative Theology: Interreligious Insights from the Next Generation"
}

Edward T. Ulrich

Follow this and additional works at: https://digitalcommons.butler.edu/jhcs

Part of the Religion Commons

\section{Recommended Citation}

Ulrich, Edward T. (2011) "Book Review: "The New Comparative Theology: Interreligious Insights from the Next Generation"," Journal of Hindu-Christian Studies: Vol. 24, Article 19.

Available at: https://doi.org/10.7825/2164-6279.1496

The Journal of Hindu-Christian Studies is a publication of the Society for Hindu-Christian Studies. The digital version is made available by Digital Commons @ Butler University. For questions about the Journal or the Society, please contact cbauman@butler.edu. For more information about Digital Commons @ Butler University, please contact digitalscholarship@butler.edu. 
68 Book Reviews

virtues simply hang on the wealth or riches of a person!!” (Nîti-śatakam 33)

(Miller translation, verse 51 [p. 41]): “A man of wealth is held to be high-born / Wise scholarly and discerning / Eloquent and even handsome - All virtues are accessories to gold!”)

Biblical verse: "I tell you solemnly: It will be very hard for a rich person (i.e., a person whose heart is attached to worldly wealth) to enter into Heaven. A camel can pass through the eye of a needle more easily than a rich man (man of attachment) can enter into Heaven." (Matthew 19.23)

A second seems to intend highlighting disillusionment with ordinary life, perhaps the difference in efficacy between karmic detachment and a devotion turn to the Lord:

"O Lord, I long for the day when I can root out all my karmas (sediments of all past actions), and keep myself utterly disinterested in the world; I yearn for living the life of a self-composed, sky-clad mendicant with the begging bowl in hand." ( Vairāgya-śatakam 89)

(Miller translation, verse 185 [p. 137]): "O Beneficent Siva, / Behold a solitary man, / Free from desire, tranquil, / Drinking from his hands, / Wearing the sky as his raiment. / When shall I master the way / To root out the store of my karma?)

"Thy face, O Lord, I seek. Hide not your face from me. Lord, make your face shine upon Your servant. My eyes shed streams of tears." (Psalms 27.8-9; 119.135-136)

A third pairing may be intended to highlight a still greater contrast between a sentiment of Bhartrhari and that of a Gospel author:

"As long as the woman is within sight, so long is she honey or ambrosia; but when she is out of sight, she is worse than poison." (Śrngāra-śatakam 43)

(Miller translation, verse 125 [p. 93]): "Woman rests ambrosial / Within our vision's pale, / But woman vanished from our sight / Is greater bane than poison.")

Biblical verse: "Make friends with the perishable worldly wealth so that, on leaving this earthly home, you may be welcomed in the Eternal Home, Heaven." (Luke 16.9)

That Kattackal gives us no guidance may in a way be a virtue of the project. In the reading of poetry and in comparative studies, there is merit in compelling the reader to think through the examples independently, as bare, unexplained juxtapositions that leave the work to us. It is our task to discover some consonance between Bhartrhari and the Bible, some interestingly different perspective on a problem in human living, or some sharper difference between two worldviews.

Nevertheless, the book sorely needs an introduction or even a reference back to Kattackal's previous comparative studies if those contain explanations of his method. This would help us to understand Bhartrhari's work, and also to know something at least of Kattackal's own wisdom regarding the pairings he makes and what he hopes to accomplish by them.

Francis X. Clooney, S.J.

Harvard Divinity School

\section{The New Comparative Theology: Interreligious Insights from the Next Generation. Ed. Francis X. Clooney. New York: T \& T Clark International, 2010, xix +208 pp.}

IN the 1990s Francis Clooney and James Fredericks made a stir among certain circles in theology and religious studies. In their respective books, Theology after Vedanta (1993) 
and Faith among Faiths (1999) they proposed a new approach to comparison, which they called "comparative theology." Rather than comparing religion from a presumed neutral vantage point, or simply underscoring areas of overlap, comparative theology proceeds from a committed faith perspective, makes precise comparisons rather than sweeping claims, and focuses on differences. The main goal is not to formulate new and better theories of religion but to rethink Christian faith in light of insights from another tradition. In the past two decades comparative theology has expanded greatly, with a host of scholars banding together under its flag. In The New Comparative Theology some of the younger scholars comment on the state of the discipline.

Unexpectedly, the book does not heap adulation on the field, for the majority of the contributors critique the area, with the hegemony of the religious and cultural backgrounds of the comparativist as a main theme. Although the book critiques the field they founded, Clooney and Fredericks are delighted by the book, the former writing that "good, hard interrogation benefits what is still a young field" and Fredericks delighted by the wide variety of concerns and directions brought forth by the contributors (xix, 200). This review will cover some points made by three contributors: Kristin Kiblinger, Michelle Voss Roberts, and Tracy Tiemeier.

Kiblinger focuses on the relationship between comparative theology and the theology of religions, the latter area addressing issues such as the salvation of non-believers. In Theology after Vedanta Clooney criticized then current theologies of religion for being abstract and too broad in nature, without demonstrating much knowledge of the concerned religions. In Faith among Faiths Fredericks argued for a separation between the theology of religion and comparative theology, arguing that the former is not helpful to the latter. However, Kiblinger points out that since the 1990s more sophisticated theologies of religion have emerged, and she gives a variety of examples. She concludes that it is time for the comparativist to take into consideration theologies of religion. Furthermore, she states that it is impossible for the Christian scholar to approach the comparative task without some theological presuppositions. By admitting these presuppositions with an explicitly formulated theology of religion the comparativist will be more honest and will thereby have a better chance of moving beyond the hegemony of his or her religious background (31).

Whilst Kiblinger argues for a closer connection between the theology of religion and comparative theology, Michelle Voss Roberts argues for a close connection between feminist theology and comparative theology. A goal of the comparativist is to understand the other religion as an insider does. Hence, comparativists have typically focused on major figures, such as Aquinas and Buddhaghosa. However, Roberts suggests that the comparativist focus on the "outsiders within," on those who are at the lower end of the power structures in the concerned religions. Feminist theology can help the comparativist to be aware of the marginalized voices in a tradition and to be aware of andocentric presuppositions when studying the work of major figures. Conversely, the feminist can learn from the comparativist the care and caution advocated by Clooney and Fredericks in analyzing a tradition, rather than racing to a conclusion to support an agenda (127).

Tiemeier argues for connecting comparative theology with liberation theology. She is concerned that the comparativist may be wrapped up in comparing another tradition to Christianity without having any connection to the community of the other tradition. To use the texts and ideas of that community for deepening one's own faith without taking any responsibility for that community amounts to exploitation: "If comparative theologians do not more carefully interrelate culture, religions, and liberation, they run the (even if unintended risk) of being at best irrelevant and at worst a tool of the new imperialism." Assuming some responsibility for the concerned religious communities has the potential not just to benefit those communities but the discipline itself of comparative theology, for relating it to "cultural and socio-political considerations" will help it to "enjoy a broadened appeal that will bring more students, scholars, theologians, activists, clergy, and lay persons to the comparative theology 
table" (149).

Although taking the critiques seriously, Clooney gives some good responses at the end of the book. In reading his response to Kiblinger's critique one is reminded of the Buddhist parable of the arrow: What difference does it make to the practical process of extracting the arrow to know who shot it? Clooney states, "In the end, it is not clear how my own work, such as my current exploration of the presence and absence of God in the traditions of the Song [of Songs] and Tiruvaymoli, would be improved by constructing for it an explicit Christian theology of religions that might then be applied to Srivaisnava Hinduism" (196). With regard to the critique that he and other comparativists have not escaped far enough from their roots because they don't consider "outsiders within," he writes, "There is no end to the broadening, corrective process, and we need also to be concerned about race, literacy and orality, economic status, and how different religions need to be treated differently. The list of concerns can become overwhelming, and we will end up focusing on some correctives more than others" (197).

This book should be a standard component of the library of the comparativist. Through critiquing the field and through its many examples of comparison the book shows new possibilities and directions for comparative theology.

Edward T. Ulrich

University of St. Thomas

\section{Comparative Theology and the Problem of Religious Rivalry. By Hugh Nicholson. New York: Oxford University Press, 2011. 320 pages}

HUGH Nicholson believes comparative theology to be an undertheorized discipline. The lack of fundamental reflection, in his view, presents at least two problems. One, it marginalizes comparative theology within the broader theological discourse, since comparative theology cannot establish its own methodological validity (47). Second, the lack of fundamental reflection increases the likelihood that comparative theology itself will misstep as it pursues comparison without adequate epistemological or ethical reflection. Nicholson's book attempts to address these problems by providing ethical and epistemological reflection on comparative theology and the problem of religious rivalry.

For such a thoughtful and lengthy book, a review can only provide the most basic summary. In order to focus this review, I will concentrate on the constructive portions of Nicholson's groundbreaking study.

Nicholson seeks to disabuse comparative theologians of the myth that theirs is an innocent, apolitical discipline. Instead, comparative theology is, along with all theology, a political endeavor. Indeed, comparative theology as a discipline is especially fraught with politics, as it necessarily invokes the power of oppositional identity. While comparative theologians may consider themselves enlightened practitioners of interreligious discourse, failure to acknowledge the dangers inherent in such discourse risks real harm. Nicholson's book plunges to the heart of this problem by addressing the problem of oppositional identity in comparative theology (ix-x).

Nicholson diagnoses two moments in the development of an oppositional, exclusive, political identity. The first moment involves the "political" act of exclusion itself. Relying on the work of Mark Heim and Carl Schmitt, Nicholson deems this moment to be inevitable. All social, political, and theological positions are exclusive. Sure, exclusivism excludes pluralism. But just as surely, pluralism excludes exclusivism (8).

Nicholson concludes that exclusion, hence politics, extends "all the way down". He devotes Chapter Two of his book to a study of "The 